\title{
対人援助職者の感情状態と関連する職業生活出来事 に着目したうつ軽減の視点
}

職業生活出来事がポジティブ感情またはネガティブ感情を媒介してうつに与える影響の分析を通して

○森本寛訓 ${ }^{1} \cdot$ 瀧川真也 $^{2} \cdot$ 長田久雄 ${ }^{3}$

( ${ }^{1}$ 川崎医療短期大学・ ${ }^{2}$ 川崎医療福祉大学・ ${ }^{3}$ 桜美林大学)

キーワード : 対人援助職者, 職業生活出来事, うつ

\begin{abstract}
The viewpoint of alleviating depression in human care service professionals focused on their work life events related to affective states Hiromichi MORIMOTO ${ }^{1}$, Shinya TAKIGAWA ${ }^{2}$ and Hisao OSADA $^{3}$
\end{abstract}

$\left({ }^{1}\right.$ Kawasaki College of Allied Health Professions, ${ }^{2}$ Kawasaki University of Medical Welfare, ${ }^{3}$ J.F.Oberlin University)

Key Words: human care service professionals, work life events, depression

\section{目的}

対人援助サービスは対人援助職者の行為そのものである。 ゆえに対人援助サービスの充実は対人援助職者自身の心理状 態によって, その充実の程度が左右される。対人援助職者の 心理状態を良好に維持することは, 対人援助サービスの充実 を図るためにも重要であるといえる。筆者らは現在まで対人 援助職者のポジティブ，ネガティブ感情と関連するポジティ ブ, ネガティブ職業生活出来事 (それぞれ PWLE (Positive Work Life Events), NWLE(Negative Work Life Events) とする) に 着目し, 研究を進めてきた（森本・神田・長田, 2011)。本研 究ではポジティブ感情とネガティブ感情がうつ(depression) の構成要素であること（Watson \& Kendall, 1989）をふまえ, PWLE はPA を媒介して, また NWLEはNA を媒介してうつに与 える影響, 寸なわち媒介効果について分析し，うつを軽減す る視点に関して考察した。

\section{方 法}

調査対象者 近畿・中国地方の医療・福祉施設従事していた 3 職種の対人援助職者 (看護職員と介護職員および监童養護 職員) 929 人を対象とした。調査期間と手続き 2008 年 9 月 から 10 月にかけて質問紙法による調査を実施した。調查前に は調查対象者が従事する医療・福祉施設の管理者に対し調査 内容について説明を行い, 同意を得た。調査内容 PWLE と NWLE は森本他 (2011) において作成した質問項目で測定した。 PWLE と NWLE はそれぞれ “職員間の関係”と“職場での役割” の 2 下位尺度で構成される。うつは日本語版 CES-D（島・鹿 野・北村・浅井, 1985) で測定した。ポジティブ感情とネガ ティブ感情は日本語版 PANAS（佐藤・安田, 2001）で測定し た。データの整理 PWLEと NWLE は下位尺度ごとに得られた データを総計し, 得点化した。日本語版 CES-D で得られたデ 一タは島他（1985）に従って集計し, 得点化した。日本語版 PANAS で得られたデータは各下位尺度で総計し, 得点化した。 それぞれの得点は “P1 (PWLEの職員間の関係)”“P2 (PWLEの 職場での役割)”“N1（NWLEの職員間の関係）”“N2（NWLE の職 場での役割)”“D (CES-D)”“PA（ポジティブ感情）”“NA（ネ ガティブ感情)”と命名した。

\section{結 果}

本研究ではPWLE と NWLE を予測変数, うつを応答変数, PA とNA を媒介変数とした。そこで媒介効果をBaron \& Kenny (1986) を参考にして分析した。この分析は (a)から (e) の 5 段階で行われた。(a). P1，P2，N1，N2 を予測変数，D を 応答変数とした一般線形モデル分析を行い, 各予測変数の係 数 $\left(\mathrm{a}_{\mathrm{P} 1}, \mathrm{a}_{\mathrm{P} 2}, \mathrm{a}_{\mathrm{N} 1}, \mathrm{a}_{\mathrm{N} 2}\right)$ を確認した。(b). P1, P2, N1, N2 を 予測変数, PA を応答変数とした一般線形モデル分析を行い, $\mathrm{P} 1$ と $\mathrm{P} 2$ の係数 $\left(\mathrm{b}_{\mathrm{P} 1}, \mathrm{~b}_{\mathrm{P} 2}\right)$ を確認した。 $(\mathrm{c})$. P1, P2, N1, N2
を予測変数, NA を応答変数とした一般線形モデル分析を行い, $\mathrm{N} 1$ と $\mathrm{N} 2$ の係数 $\left(\mathrm{c}_{\mathrm{N} 1}, \mathrm{c}_{\mathrm{N} 2}\right)$ を確認した。(d). P1, P2, N1, N2, PA, NA を予測変数, D を応答変数とした一般線形モデル分析 を行い, PA と NAの係数 $\left(\mathrm{d}_{\mathrm{PA}}, \mathrm{d}_{\mathrm{NA}}\right)$ を確認した。ここで (a)

（b）（c）（d）の一般線形モデル分析では予測変数および応答 変数として用いる得点を事前にすべて標準化した。また今回 は 3 職種の対人援助職者から得られたデータを分析するため 職種ごとに切片と傾き（係数）が異なることも予測された。 よってこの予測を考慮した一般線形モデルを設定し, データ の分析を行った。(a)から (d)の分析の結果, 確認した係数は 全て統計的有意であった。（e）. 最後に（b）（c）（d）より媒 介効果を表す係数の積, すなわち $b_{\mathrm{P} 1} \times \mathrm{d}_{\mathrm{PA}}, \mathrm{b}_{\mathrm{P} 2} \times \mathrm{d}_{\mathrm{PA}}, \mathrm{c}_{\mathrm{N} 1} \times \mathrm{d}_{\mathrm{NA}}$, $\mathrm{c}_{\mathrm{N} 2} \times \mathrm{d}_{\mathrm{NA}}$ の 95\%信頼区間を PRODCLIN（Tofighi \& MacKinnon, 2011) で求めた。結果は $b_{P 1} \times d_{P A}[-0.116,-0.055], b_{P 2} \times$ $\mathrm{d}_{\mathrm{PA}}[-0.119,-0.058], \mathrm{c}_{\mathrm{N} 1} \times \mathrm{d}_{\mathrm{NA}}[0.066,0.139], \mathrm{c}_{\mathrm{N} 2} \times \mathrm{d}_{\mathrm{NA}}[0.165$, 0.259]であった。以上より PWLE と NWLE がそれぞれ PA と NA を媒介してうつに影響を与える媒介効果は認められると判断 した。

\section{考 察}

本研究ではPWLE がポジティブ感情を媒介して, また NWLE がネガティブ感情を媒介してうつに与える影響, 寸なわち媒 介効果について分析を行った。うつは様々な心身症状からな るが, 感情面の不調はその症状のひとつである。今回の研究 では, うつの感情面が低ポジティブ感情と高ネガティブ感情 で構成されること（Watson \& Kenda11, 1989）より，ポジティ ブ感情と正の相関関係にある PWLE と, ネガティブ感情と正の 相関関係にある NWLE には, それぞれポジティブ感情とネガテ イブ感情を媒介してうつに影響を及ぼす，媒介効果があると 考えた。分析の結果, PWLE 体験はPA を媒介してうつを低減 し，NWLE 体験はNA を媒介してうつを増大させることが認め られた。したがって PWLE 体験を高める，または NWLE 体験を 低めるという視点は, 対人援助職者のうつ軽減について有効 な示唆を与えてくれるものと思われる。

\section{引用文献（主な論文のみ）}

Baron, R. M., \& Kenny, D. A. (1986). The moderater-mediator variable distinction in social psychology research: conceptual, strategic, and statistical considerations. Journal of Personality and Social Psychology, 51(6), 1173-1182.

森本寛訓・神田有希恵・長田久雄 (2011). 対人援助職者の感 情状態と関連する職業生活出来事の検討 ヒューマン・ ケア研究， $12 ， 35-51$.

この研究は科研費（19730453）の助成を受けて行われた。 